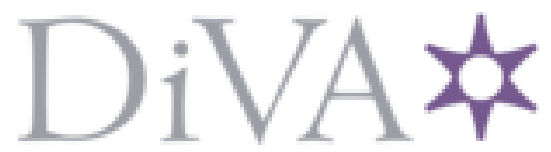

http://www.diva-portal.org

\title{
Postprint
}

This is the accepted version of a paper published in European Constitutional Law Review. This paper has been peer-reviewed but does not include the final publisher proof-corrections or journal pagination.

Citation for the original published paper (version of record):

Öberg, J. (2017)

The Rise of the Procedural Paradigm: Judicial Review of EU Legislation in Vertical

Competence Disputes.

European Constitutional Law Review, 13(2): 248-280

https://doi.org/10.1017/S1574019617000086

Access to the published version may require subscription.

N.B. When citing this work, cite the original published paper.

Permanent link to this version:

http://urn.kb.se/resolve?urn=urn:nbn:se:oru:diva-57956 


\section{THE RISE OF THE PROCEDURAL PARADIGM- JUDICIAL REVIEW OF EU LEGISLATION IN VERTICAL COMPETENCE DISPUTES}

\section{Basic context- setting out the problem of competence review of EU legislation}

A central question for any court engaged in constitutional review (ie where statutes are scrutinized for their conformity with principles enshrined in constitution or other basic laws ${ }^{1}$ ) is how rigorously the Court should scrutinize legislation. A court's choice is arguably a twofold matter of institutional and constitutional choice. In a federal jurisdiction (and systems of a similar nature) it appears that the intensity that is used when the court reviews legislation (deriving from the central legislator) determines not only the balance of powers between the court and the legislator but also between the central government and its component entities. ${ }^{2}$ Stringent review of federal legislation tends, put simply, to favour the states and the courts vis- á- vis the central legislator. More leeway to the legislator instead suggests that the court may not wish to encroach upon the prerogative of the legislator to make policy nor impose excessive burdens on the federal legislator in relation to the states. ${ }^{3}$ The question of intensity and standard of judicial review is nevertheless thereto a question of who, the Court or another societal decision-maker, should make the final decision in a democracy of what the constitution means. ${ }^{4}$ This is a question of comparative institutional choice. Courts tend to engage in more deferential review where it enjoys inferior (democratic) legitimacy, competence and expertise than the legislator to analyse a certain question. ${ }^{5}$ Regardless whether one wishes to conceive judicial review primarily as a constitutional question or an institutional one, it seems that any judicial review court would ultimately have to address these two questions.

This essay intends to contribute to this debate by exploring the role of the European Court of Justice in judicial review of EU legislation in vertical competence disputes (ie litigation where EU legislation has been pleaded to be contrary to the constitutional principles of conferral,

\footnotetext{
${ }^{1}$ See Jeremy Waldron, The Core of the Case Against Judicial Review', 115 (2006) Yale Law Journal 1346, 1357-58.

${ }^{2}$ Koen Lenaerts, 'Constitutionalism and the Many Faces of Federalism', 38 (1990) American Journal of Comparative Law 205, 206.

${ }^{3}$ See Paul Craig, 'The ECJ and Ultra vires action: a conceptual analysis' (2011) 48 Common Market Law Review 395, 396-397. 410; Stephen Weatherill, 'The limits of legislative harmonisation ten years after Tobacco Advertising: how the Court's case law has become a "drafting guide' (2011) 12 German Law Journal 827, 851.

${ }^{4}$ Neil Komesar, 'A Job for the Judges: The Judiciary and the Constitution in a Massive and Complex Society' (1988) 86 Michigan Law Review 658, 659.

${ }^{5}$ Ibid, 690-699.
} 
subsidiarity and proportionality $\left.{ }^{6}\right)$. The Court of Justice's role in policing the constitutional order of competences laid down by the Treaties is contested. To this date, it appears that the Court of Justice faced with complex competence/legal basis litigation has tended to address the 'constitutional question' in favour of the Union vis à vis the Member States, thus accepting the EU legislator's broad interpretation of its legislative powers. ${ }^{7}$ The Court's approach should, however, not be surprising. As contended below, it appears that the vague content of the principles limiting the exercise of EU powers has pushed the Court of Justice to the outer limits of its legitimacy as derived from the Treaties. The quasi-political and empirical questions involved in assessing the proportionality of EU legislation, what 'benefits' the internal market and the question of the right regulatory level for achieving an EU objective (subsidiarity) are all issues which the Court as an institution may be less equipped than the Union legislator to address. Thus, the 'institutional choice' has inclined to tilt in favour of the EU legislator. ${ }^{8}$

The recent Phillip Morris judgment illustrates these concerns. In this case, a revised tobacco advertising directive was contested inter alia on the ground that it prohibited the marketing of tobacco products with a 'characterising flavour', thus preventing rather than facilitating trade with regard to the product concerned. Despite this, the directive was considered as falling within the scope of Article 114 TFEU. ${ }^{9}$ The Court addressed proportionality in an equally deferential manner. It explicitly stated that the Union legislature must be allowed a broad discretion within the field of public health, as this policy involves political and social choices on its part and complex assessments. The legality of a measure adopted in that area can be affected only if the measure is manifestly inappropriate having regard to the objective which the competent institutions are seeking to pursue ${ }^{10}$ On the basis of this standard, it was well-

\footnotetext{
${ }^{6}$ See Art 5 TEU.

${ }^{7}$ See (2012) 19 Journal of European Public Policy, Special Issue: 'Perpetual momentum? Reconsidering the power of the European Court of Justice'; Alex Stone Sweet, The Judicial Construction of Europe, (Oxford University Press, 2004); Joseph H H Weiler, 'The Transformation of Europe' (1991) 100 The Yale Law Journal 2403, 2433- 2447.

${ }^{8}$ See Weatherill (n 3), 850-852.

${ }^{9}$ Case C-547/14 Philip Morris Brands and Others (Court of Justice, 4 May 2016), paras 107-125, 127-136. See for equally deferential review in relation to Article 114 TFEU: Case C-491/01 British American Tobacco (Investments) and Imperial Tobacco [2002] ECR I-11453, paras 81-88; Case C-210/03 Swedish Match [2004] ECR I-11893, paras 35-40; Case C-58/08 Vodafone [2010] ECR I-04999, paras 38-47; Case C-377/98 Netherlands $v$ Parliament and Council [2001] ECR I-07079, paras 14-18, 20-22, 24-25, 27-29.

${ }^{10}$ See Case C-547/14 Philip Morris Brands and Others (n 9), paras 165-166. This light proportionality review of EU legislation is consistent with the Court's previous case law: Joined Case C-27 and C-122/00, Omega Air and other joined cases [2000] ECR I-2569, paras 63-64; Case C-491/01 British American Tobacco (Investments) and Imperial Tobacco (n 9), para 123; C-84/94 United Kingdom v Council [1996] ECR I-05755, para 58.
} 
anticipated that the Court found the measure to be proportionate. ${ }^{11}$ The Court of Justice's subsidiarity assessment also demonstrated a very low-intensity review. Whilst the Court did consider the substantive part of the subsidiarity test, its approach to procedural subsidiarity was strikingly deferential. The Court stated in one sentence that there was sufficient information in the impact assessment and the explanatory memorandum demonstrating the need for Union action. ${ }^{12}$ Phillip Morris consolidates the Court's approach to judicial competence review of EU legislation which so far can be characterised as deferential and perhaps incapable of protecting the distribution of competences between the Member States and the Union.

In the light of this, this article examines how, ie with what intensity and what test, the Court of Justice should enforce the constitutional principles of conferral, subsidiarity, and proportionality in a challenge to EU legislation. This article advances the argument that a more intense 'process-based' review rather than 'substantive' review ${ }^{13}$ of EU legislation is an appropriate judicial safeguard of federalism. The article is structured as follows: Section 2 evaluates the rationales behind the Court's conventional approach to competence review by examining how the framing of the Treaties have influenced the Court of Justice's capacity to engage in judicial review. Section 3 then considers the case for procedural review. It will be argued that institutional considerations and the advancement of a legitimacy discourse support the view that procedural review is the appropriate form of review (or 'paradigm') for enforcing the principles in Article 5 TEU. Section 4 subsequently develops a test for judicial review, based upon an analysis of the Court's ruling in Spain v Council that the Court can apply to assess the legality of EU legislation. The final section summarises the argument and reflects on the implications of the proposed model.

\section{Institutional and conceptual problems of vertical competence review}

This section provides a more detailed account of the concerns against judicial review raised in the introduction. Institutional arguments against judicial review are commonplace in

\footnotetext{
${ }^{11}$ Case C-547/14 Philip Morris Brands and Others (n 9), paras 171-191; C-210/03 Swedish Match (n 9), paras 48-57; Case C-176/09 Luxembourg v Parliament and Council [2011] ECR I-03727; paras 62-72.

${ }^{12}$ See Case C-547/14 Philip Morris Brands and Others (n 9), paras 220-226. See also Joined cases C-154/04 and 155/04 Alliance for Natural Health and others [2005] ECR I-06451, paras 104-107; Case C-233/94 Germany v Parliament and Council [1997] ECR I-02405, paras 26-28; Case C-58/08 Vodafone and Others (n 9), paras 7280 , for the Court's low intensity review of subsidiarity.

${ }^{13}$ The distinction between these two forms of review is outlined below in section 3 .
} 
constitutional discourse. The premise within the context of review of EU legislation ${ }^{14}$ is principled analysis of the kind required by the principles in Article 5 TEU involving complex empirical and normative judgment of the effectiveness and appropriateness of different EU policies is beyond the capacities of the EU courts. This is because in such cases the Union Courts are operating at the border of judicial legitimacy derived from their authority and competence. ${ }^{15}$ A conventional understanding of democratic legitimacy thereto suggests that the primary responsibility for policy-making should reside with the EU political institutions which enjoy the legitimacy to perform this task. Only a political procedure can ensure that important decisions are taken after a transparent procedure in which all relevant stakeholders can participate and engage in a genuine political debate over the balance to be struck between conflicting interests. ${ }^{16}$

The institutional problems of judicial review within the EU context are reinforced by the conceptual problems of the existing limits on EU competences. A lack of clarity as to the meaning of the principles in Article 5 TEU means that if the Court of Justice is to engage in proper substantive judicial review, it must become involved in assessing open-ended political, economic and social issues. ${ }^{17}$ The Court is fundamentally ill-equipped for this task. Furthermore, since several important legislative powers such as Article 114 and Article 352 TFEU are framed as purposive and functional powers defined by the goal to be achieved, ${ }^{18}$ the Treaties have provided grounds for an expansive interpretation by the Union legislator of the scope of the Union's powers. ${ }^{19}$ Appeals to objectives or policies cannot work as a limit to EU competences since they do not provide the Court with hard legal criteria to resolve disputes. $^{20}$ The teleological imperative of further integration enshrined in the design of the EU legal order has furthermore placed constraints on the Court to effectively enforce the vertical order of competences. If the Union is to achieve the objectives set out in the Treaties and resolve functional problems, the necessary powers must be placed at the service of the

\footnotetext{
${ }^{14}$ See for the general institutional argument against judicial review: Komesar (n 4), 665, 668-690, 697; Paul Daly, A Theory of Deference in Administrative Law: Basis, Application and Scope (Cambridge University Press, 2012) 70-137.

${ }^{15}$ See Joanne Scott and Susan Sturm 'Courts as Catalysts: Rethinking the Judicial Role in New Governance' (2007) 13 Columbia Journal of European Law 565, 569.

${ }^{16}$ See Janneke H Gerards, 'Pluralism, Deference and the Margin of Appreciation Doctrine', (2011) 17 European Law Journal 80, 86; Waldron (n 1).

${ }^{17}$ See Robert Schütze, From Dual to Cooperative Federalism (Oxford University Press, 2009) 136-139.

${ }^{18}$ See Gareth Davies, 'Democracy and Legitimacy in the Shadow of Purposive Competence' (2015) 21 European Law Journal 2, 4, 6. doi:10.1111/eulj.120794.

${ }^{19}$ See Leon N Lindberg, The Political Dynamics of European Economic Integration (Stanford University Press 1963) 284, 290, 293.

${ }^{20}$ See Stephen Weatherill, 'Competence creep and competence control' (2004) 23 Yearbook of European Law 1, 13-17, 25, 27, 46, 49; Schütze (n 17) 136-156.
} 
Union. ${ }^{21}$ The Court has consistently with this imperative supported a broad interpretation of the scope of Union competences in order to enhance the effectiveness of Union law. ${ }^{22}$ The Court of Justice's position in the legal order of the Union furthermore counters against strict competence review. The Court is in fact an EU institution (and an agency of the Union) and may have institutional incentives to protect that interest. Certainly the behaviour of the Court in the past suggested that it viewed itself as a force for integration rather than as a guardian of Member State interests. ${ }^{23}$

The link between institutional, teleological and theoretical considerations in determining the intensity of judicial review is demonstrated by the Court of Justice's approach to scrutiny of legislation adopted under Article 114 TFEU. The wording of this provision-giving the EU legislator power to adopt the measures 'for the approximation of the provisions laid down by law, regulation or administrative action in Member States which have as their object the establishment and functioning of the internal market'-suggests that the EU legislator has been conferred with a wide margin of discretion as to how it executes the internal market objectives. This discretion is well-recognised by the Court. For example, the Court has upheld the view, that the authors of the Treaty intended to confer a freedom of choice to the Union legislator under Article 114 TFEU depending on the general context and the specific circumstances of the matter to be harmonised, and with regards to the most appropriate mode and method for achieving the objectives of the internal market. ${ }^{24}$ Ultimately, the Court's deferential approach has resulted in feeble enforcement of Article 114 TFEU. ${ }^{25}$

The reasons behind the Court's cautious stance to subsidiarity and proportionality can be traced to similar concerns. The subsidiarity principle forces the Court to engage in an assessment of the complex political-economic questions of reliance on Member State alternatives, and seek compromise using the values of efficiency and democracy in order to determine whether there is a need for EU action. These are matters of political judgment that the EU legislative institutions for reasons of legitimacy and competence are better equipped to

\footnotetext{
${ }^{21}$ See Pierre Pescatore, Law of Integration: Emergence of a New Phenomenon in International Relations, Based on the Experience of the European Communities (Vienna, Springer, 1974, English Translation) 40-43, 50-51.

${ }^{22}$ See Loïc Azoulai, 'Introduction: the Question of Competence' in Loïc Azoulai (ed), The Question of

Competence in the European Union (Oxford University Press, 2014) 2, 5-6.

${ }^{23}$ See the literature in $\mathrm{n} 7$ for support of this point.

${ }^{24}$ See Case C-210/03 Swedish Match (n 9), paras 33-34; Case C-58/08 Vodafone and Others (n 9), para 35.

${ }^{25}$ See the cases referred to in $\mathrm{n} 9$.
} 
evaluate. ${ }^{26}$ The Court's own perception of its institutional capacity does in fact permeate its approach to subsidiarity review which is marked by an extremely deferential review of the principle. ${ }^{27}$ When it comes to the Court's proportionality review of general EU policy schemes, it seems to be recognised that EU political institutions make policy assessments which involve complex factors to be balanced and weighed by the EU legislature. The EU courts are not well equipped to make these assessments and should therefore not overturn the EU legislator's political choices. ${ }^{28}$ These general considerations have led the Court to review proportionality on the basis of a 'manifestly inappropriate' test which has resulted in poor enforcement of Article 5(4) TEU. ${ }^{29}$

Two points summarize the discussion so far. The first is the connection between the clarity of the Treaty limits in Article 5 TEU and institutional arguments for deferential judicial review. Since the Court does not have any clear criteria against which it can assess conformity with the constitutional principles in Article 5 TEU, it must venture into the borders of its authority and analyse issues beyond the law to engage in the review required by this provision. The Court is apparently not comfortable to take on this task. Secondly, there is force in the institutional arguments for lenient review of EU legislation. It appears axiomatic that the Court of Justice should, given its questionable expertise and legitimacy relative to the legislator, neither substitute the judgement of the appropriateness of EU measures or political choices where the EU legislature were required to balance divergent political interests against each other. This suggests that it may be difficult for the Court to engage in stronger substantive review as this would mean that the Court would have to go beyond its legitimacy and competence by reconsidering the EU legislator's political decisions. Notwithstanding these observations, there is still hope for more intense judicial scrutiny of the principles in Article 5 TEU. As contended in the remainder of this article, in order to respond to the arguments for deferential review advanced above, the Court is encouraged, to develop its current procedural form of review.

\footnotetext{
${ }^{26}$ See George A Bermann 'Taking Subsidiarity Seriously' (1994) 94 Columbia Law Review 332, 337, 385-386, 391-394,400; Antonio Estrella, The EU Principle of Subsidiarity and Its Critique (Oxford University Press, 2002) $139,147,165,176$.

${ }^{27}$ See $\mathrm{n} 12$ for references to relevant case law.

${ }^{28}$ See Paul Craig, EU Administrative Law (Oxford University Press, 2012) 592-593,600-604, 629-30, 639.

${ }^{29}$ See the cases in $\mathrm{n} 11$ for support.
} 
Because of the numerous terms used in the literature, an account of a definition of procedural review $^{30}$ is necessary for the purposes of the present article. The article proceeds from a strict understanding of procedural review that compels the Court to consider whether the reasoning and evidence of the EU legislator is sufficient to justify the exercise of general legislative powers. ${ }^{31}$ This suggests that the Court, as a minimum, should consider whether the EU legislator conformed to the procedural steps and structures mandated by the Treaties. ${ }^{32}$ On the one hand, this definition is broader than that of 'pure' procedural review which entails that courts in its review focus exclusively on whether the legislature met certain statute-based procedural requirements in the legislative process. On the other hand, it is narrower than 'substantive review' that requires courts to determine the validity of legislation based strictly on an examination of the statute's content. ${ }^{33}$

What then are the pros and cons of procedural review? The key argument in support of this form of review is that it responds to the institutional objections against the Court of Justice's capacity to engage in competence review. ${ }^{34}$ Whilst the EU legislator's choice of policy may go beyond the Court's authority to review, the question of whether EU legislative institutions has substantiated its legislative choices is an issue that the Court is well-equipped to examine. ${ }^{35}$ Procedural requirements relating to the adequacy of the evidential basis for decision-making also helps remedy the problems of reviewing the constitutional principles in Article 5 TEU. $^{36}$ Since procedural review requires policy-makers to collect evidence, the Court will have at its disposal a useful mass of materials that will help it to determine the legality of a given act. ${ }^{37}$

The literature has, nevertheless, identified several problems with this type of review, namely that: i) intense procedural review regularly is transformed to substantive review, ii) procedural

\footnotetext{
${ }^{30}$ See Alberto Alemanno 'The Emergence of Evidence-based Judicial Reflex: A Response to Bar-Siman-Tov's Semiprocedural Review' (2013) 1 The Theory and Practice of Legislation 327; Dan T Coenen, 'The Pros and Cons of Politically Reversible 'Semisubstantive' Constitutional Rules' (2008-2009) 77 Fordham Law Review 2835; Ittai Bar-Siman-Tov, 'Semiprocedural Judicial Review’ (2012) 6 Legisprudence 271.

${ }^{31}$ See Case C- 310/04 Spain v Council [2006] ECR I-07285, paras 122-123.

${ }^{32}$ See Koen Lenaerts, 'The European Court of Justice and Process-Oriented Review' (2012) 31 Yearbook of European Law 3, 4, 15.

${ }^{33}$ See Bar-Siman-Tov, 'Semiprocedural Judicial Review' (n 30), 272, 275, 279-280; Alemanno, 'evidencebased judicial reflex' (n 30) 332, 334-335.

${ }^{34}$ See above text to nn 7-11.

${ }^{35}$ See Lenaerts, 'Process-Oriented Review' (n 32) 15-16; Scott and Sturm (n 15) 575.

${ }^{36}$ See section 2 for an outline of this problem.

${ }^{37}$ See Scott and Sturm (n 15) 582, 586, 588, 590; Alemanno, 'evidence-based judicial reflex' (n 30) 333-336, 338.
} 
review gives too much discretion to judges in deciding what relevant reasoning and information is, iii) procedural review is contrary to the principle of institutional balance (and the principles of democracy). Each of these will be considered in turn.

Martin Shapiro has expounded on the challenge for courts to maintain review of a 'procedural' nature. He contends there is a virtually unidentifiable line between intense procedural review for 'adequate' reasoning and substantive review as regards giving reasoning requirements. ${ }^{38}$ Referring to the example of the reasoning requirement in the US Administrative Procedure Act, Shapiro expresses concerns that procedural requirements imposed by courts may develop to an intrusive style of substantive review. This occurs when the court not only looks at the purely procedural question of whether reasoning exists, but also at the substantive question of whether the reasoning is sufficient. Procedural review also gives judges unbridled discretion in deciding in each case what the relevant information is, and what would constitute appropriate reasoning. ${ }^{39}$

There is force in Shapiro's criticism. It is clear that procedural review may turn into substantive review if the Court of Justice assesses the adequacy of the reasoning given. The scope of the suggested procedural review is, however, limited. Procedural review does not suggest review of the appropriateness of legislation or that the Court substitutes the EU legislator's political choices. Instead, it grants a substantial amount of discretion to the EU legislature in the field of the common policies as long as the legislature has considered the evidence of the case. Neither does procedural review suggest that the Court should track the whole legislative procedure. It is limited to considering whether legislative choices fit with the reasoning and the evidence in the legislative background documents (impact assessments, explanatory memoranda, and proposals/amendments to the legislative proposal deriving from EU institutions). ${ }^{40}$

Can strict procedural review be distinguished from substantive review? Admittedly, there is a very fine line between these two forms of review. If it is possible to uphold the distinction, the line between 'strict procedural review' and 'substantive review' is crossed if the Court commences to assess whether the EU legislator's choice has been the best or most appropriate

\footnotetext{
${ }^{38}$ See Art 296 TFEU.

${ }^{39}$ See Martin Shapiro, 'The Giving Reasons Requirement' (1992) University of Chicago Legal Forum 179, 179, 184-186, 188-189, 202, 206, 209-210, 218; Christopher Bryant and Timothy J Simeone, 'Remanding to Congress: The Supreme Court's New “On the Record” Constitutional Review of Federal Statutes', 86 (2001) Cornell Law Review 328, 395-396.

${ }^{40}$ See Lenaerts, 'Process-Oriented Review' (n 32), 4, 15; Emily Hammond and David L Markell, 'Administrative Proxies for Judicial Review: Building Legitimacy from the Inside-out' (2013) 37 Harvard Environmental Law Review 313, 316, 321-326; Scott and Sturm (n 15) 590-591.
} 
choice. ${ }^{41}$ Shapiro illustrates himself where the border may be drawn between strict procedural review and substantive review through the Remia case ${ }^{42} \cdot{ }^{43}$ In Remia, the Court of Justice held that it had competence to review whether the simple, first order facts were accurately stated, and whether the legislator's reasoning indicated that the legislator had considered those facts. The Court, however, disclaimed competence to review the economic/political analysis that the legislator had applied to the facts in order to reach its decisions. ${ }^{44}$

Shapiro's criticism that judicially created procedural demands may give too much discretion to courts should also be taken seriously. It is recognised that the Court of Justice might, when faced with an uncertain construction of Union legislation, in pursuing strict procedural review be led to a different mode of analysis to which it may not be accustomed. This problem is, however, not unique to demanding procedural review. The Court's substantive review in fundamental rights cases and its proportionality jurisprudence within the context of the fundamental freedoms is engrained with difficult political judgments as well as open-ended assessments of the appropriateness of certain measures. Whilst rights-based review always has been considered the proper domain of courts in terms of legitimacy and expertise ${ }^{45}$ and the Court's strict proportionality review can be defended on the basis that it concerns prima facie infringements by Member States of the fundamental freedoms ${ }^{46}$, the Court of Justice appears equally well-equipped to enforce the principles in Article 5 TEU. It would even seem as an indispensable task for the Court of Justice, as a constitutional court, to perform this function within the European Union. ${ }^{47}$ It is therefore difficult to see why procedural forms of review assessing the adequacy of reasoning and the evidence for measures should be considered as too intrusive. ${ }^{48}$

Procedural review, although less controversial in terms of legitimacy and competence than substantive review, have still suffered from such institutional criticisms that was accounted for in section 2. US scholarship has particularly underlined the problem of separation of powers which occurs when courts engage in intense procedural review. Taking the example of

\footnotetext{
${ }^{41}$ See Case C-189/01 Jippes and Others [2001] ECR I-5689, para 83.

${ }^{42}$ See Case 42/84, Remia BV and Others $v$ Commission [1985] ECR 2545.

${ }^{43}$ See Shapiro (n 39) 214.

${ }^{44}$ See Case 42/84, Remia BV and Others v Commission (n 42), paras 34-36.

${ }^{45}$ See Craig, EU Administrative Law (n 28), 617-618.

46 Ibid 629-630.

${ }^{47}$ See Koen Lenaerts,' Federalism: Essential Concepts in Evolution -The Case of the European Union' 21 (1997) Fordham International Law Journal 746, 795-797.

${ }^{48}$ See Mattias Kumm, 'Constitutionalizing Subsidiarity in Integrated Markets: The Case of Tobacco Regulation in the European Union' 12 (2006) European Law Journal 503, 528; Gareth Davies, 'Subsidiarity: the wrong idea, in the wrong place, at the wrong time' (2006) 43 Common Market Law Review 63, 68-69.
} 
the Supreme Court's jurisprudence, Cristopher Bryant and Timothy Simeone suggest that the judiciary has no authority or legitimacy to impose requirements regarding the kind of legislative record that the legislator must compile when enacting a statute. Judgments relating to the need for legislation are often inherently value-laden, political and consigning such judgments to the judiciary flies in the face of the principle of institutional balance. This criticism is exacerbated when courts impose upon the legislature heightened judicially created requirements leading potentially to substitution of the legislator's policy choices. ${ }^{49}$

Bryant and Simeone's argument against procedural review is undoubtedly compelling. There is obviously a risk that courts, in identifying the procedural steps to be followed, might make value judgments similar to those expressed by substantive review courts. Procedural review, nonetheless, poses a lesser challenge to democratic political theory ${ }^{50}$ and the principle of institutional balance than substantive review. Intense process-based review only requires normative judgments about how decisions should be made, not judgments with reference to the content of the political decision. The aim is thus to refine rather than to frustrate democratic decision-making. ${ }^{51}$

Thereto, it is sustained that there remains, also with respect to the precepts of democracy, a legitimate place for judicial competence review within the EU political context. ${ }^{52}$ Even if one argue that courts generally enjoy less legitimacy than the political decision-maker, it appears that the political procedures in the EU is weaker in democratic terms than classical national political systems such as the United States which was used as a target for Jeremy Waldron's famous attack on judicial review. ${ }^{53}$ It seems that the present state of the EU political process, with the Union still suffering from a democratic deficit (compared to western democracies) partly undermines the classic challenge to the Court. Whilst the European Parliament is popularly elected its powers are still limited and the other EU institutions cannot claim a

\footnotetext{
${ }^{49}$ See Bryant and Simeone (n 39) 383-388, 391-392; Philip P Frickey and Steven S Smith, Judicial Review, the Congressional Process, and the Federalism Cases: An Interdisciplinary Critique' (2002) 111 Yale Law Journal 1707, 1740-44, 1750, 1754.

${ }^{50}$ See above text to $\mathrm{n} 16$ for the general democratic argument against judicial review.

${ }^{51}$ See Burt Neubome, 'Judicial Review and Separation of Powers in France and the United States' (1982) 57 New York University Law Review 363, 364-367; Harry H Wellington, 'The Nature of Judicial Review' (1982) 91 Yale Law Journal 486, 504-505.

${ }^{52}$ See Alec Walen, 'Judicial Review in Review: A Four-Part Defense of Legal Constitutionalism. A Review Essay on Political Constitutionalism, by Richard Bellamy,' (2009) 7 International Journal of Constitutional Law 329; Annabelle Lever, 'Democracy and Judicial Review: Are They Really Incompatible?' (2009) 7 Perspectives on Politics 805 for general arguments in favour of judicial review on democratic grounds.

${ }^{53}$ It is open to discussion if this is a fair comparison: see Paul Craig, 'Democracy and rule-making within the EC: An Empirical and Normative Assessment' (1997) 3 European Law Journal 105, 114-119, for a more nuanced assessment of the nature of democracy in the Union.
} 
democratic mandate. Neither the Council nor the Commission is selected by or accountable to the electorate. There are also structural limits to the realization of input democracy in the EU. The fact that the people are represented through the European Parliament and the Member States in the Council means that it is not possible under existing arrangements (where Council representatives are not chosen by the citizens) for the EU citizens to directly vote out those in power and substitute them with a different party. It is thus questionable whether Waldron's main assumption on 'democratic institutions in a good working order' ${ }^{54}$ is met with respect to the EU political procedure thus undermining the 'core case' against judicial review of EU legislation. $^{55}$

Although a strong case could be made that procedural review may, at times upset the institutional balance between courts and the legislator and be subject to similar institutional criticism in terms of legitimacy and competence as substantive review, there is still a good argument for courts to develop demanding forms of procedural review. Strict procedural review has an intrinsic value in promoting a more legitimate legislative process. The latter appears pressing since the EU still today ${ }^{56}$ post-Lisbon seems to suffer from legitimacy challenges in terms of intransparency and lack of accountability as regards political decisionmaking. A Eurobarometer survey in 2011 revealed that 42 per cent of European citizens are not satisfied with the level of transparency in the EU administration while only nine per cent are satisfied. ${ }^{57}$ The EU's specific institutional structure, the opaque decision-making procedure and the complexity of the typology of legal acts, obscure appreciation of the vertical allocation of powers and the accountability for decisions. ${ }^{58}$ Although there have been general improvements as regards access to documents and more open legislative deliberations, citizens still perceive a great distance between themselves and the governing

\footnotetext{
${ }^{54}$ See Waldron (n 1) 1361-62.

${ }^{55}$ See Paul Craig, The Lisbon Treaty: Law, politics and Treaty reform (Oxford University Press, 2011) 73-74; Ernest A Young, 'Protecting Member State Autonomy in the European Union: Some Cautionary Tales from American Federalism' (2002) 77 New York University Law Review 1612, 1638-39.

${ }^{56}$ See Gráinne De Búrca, 'The Quest for Legitimacy in the European Union', (1996) 59 Modern Law Review $349,367-376$, for earlier assessments of the state of legitimacy in the Union.

${ }^{57}$ See The European Ombudsman, 'Annual Report 2011' (2011), 6 www.ombudsman.europa.eu/activities/annualreports.faces;jsessionid=36BB77F9D3E8B63EDAAE9C73470AA 169. Accessed 23 October 2016. See also_European Commission, 'Special Eurobarometer 397-Corruption' (2014) ec.europa.eu/public_opinion/archives/ebs/ebs_397_en.pdf. Accessed 23 October 2016 for the continuous transparency problems.

${ }^{58}$ See Herwig CH Hofmann, Gerard C Rowe, and Alexander H Türk, Administrative Law and Policy of the European Union (Oxford University Press, 2011) 170-171; Craig. 'Democracy and Rule-making' (n 53), 110111.
} 
EU institutions in Brussels. It is argued that more demanding procedural review imposed by the Court will be instrumental in addressing these concerns.

The premise for this argument is that such a form of review by courts supports a discourse of legitimacy by focusing on the legislator's justification, by fostering deliberation and by structuring the exercise of public power. Procedural review has its strongest underpinnings in procedural democratic theories that consider the process by which laws are generated as the main source of legitimacy. ${ }^{59}$ Such theories contrast to substantive legitimacy theories which focus on the content of the law and its conformity with some normative moral standard. In the present context it is not necessary to determine whether it is most appropriate to endorse the procedural or substantive theories of democracy. There is particular legitimacy benefits connected to procedural justice and it is sustained that strict procedural review is apt to produce them. Several empirical studies (particularly of the US congress) indicate that a person's perception that the legislator employs fair decision-making procedures positively impacts on the social legitimacy of the legislative procedure. ${ }^{60}$ The literature on procedural justice also suggests that a deliberative process that is perceived to be fair and inclusive to differing points of view receives higher legitimacy assessments and more positive assessments of the outcome produced than one that is perceived to be closed and partial.

On the basis of the literature reviewed in the previous paragraph, it is suggested that the model of procedural review advanced here will promote the values mentioned and thus be a legitimacy-reinforcing instrument within the EU. ${ }^{61}$ The relationship between transparency and procedural review illustrates this point. In this respect, it appears that the Court of Justice's case law on the giving-reasoning requirement in Article 296 TFEU exhibits that transparency is one of the foundations for strong procedural review. Such a review requires that citizens may legitimately claim a right to know about the reasons behind a government decision. By

\footnotetext{
${ }^{59}$ See Amy Gangl, 'Procedural Justice Theory and Evaluations of the Lawmaking Process' (2003) 25 Political Behavior 119, 119-132; Ittai Bar-Siman- Tov, 'The Puzzling Resistance to Judicial Review of the Legislative Process' (2011) 91 Buffalo Law Review 1915, 1927-1931; Tom R Tyler, 'Governing amid Diversity: The Effect of Fair Decision-making Procedures on the Legitimacy of Government' (1994) 28 Law \& Society Review 809, 809-811, 813, 818-826; Michael X Delli Carpini, Fay Lomax Cook and Lawrence R Jacobs, 'Public Deliberation, Discursive Participation and Citizen Engagement: A Review of the Empirical Literature' (2004) 7 Annual Review of Political Science 315, 320, 327, 336.

${ }^{60}$ Social legitimacy, as defined here, suggests that decisions are legitimate if the relevant public sees them as deserving support for reasons beyond fear of sanctions; see Richard H Fallon, 'Legitimacy and the Constitution' 118 (2005) Harvard Law Review 1787, 1794-1801.

${ }^{61}$ See Dorota Leczykiewicz, “"Constitutional Justice” and Judicial Review of EU Legislative Acts' (2013)

Oxford Legal Studies Research Paper No 95/2013, 2-3. ssrn.com/abstract=2355961. Accessed 24 October 2016.
} 
requiring the EU institutions to substantiate their decision with reasoning and evidence, procedural review reinforce the importance of transparency in the legislative procedure. ${ }^{62}$

It is thus contended that stringent procedural review may increase both the social and legal legitimacy ${ }^{63}$ of the EU's decision-making procedures. By enforcing standards of rational decision-making and by requiring EU action to be more accountable the Court promotes the social legitimacy of the EU system of governance as a whole (and confidence among EU citizens to this system). ${ }^{64}$ The procedural review model proposed here is also capable of advancing a broader culture of justification in policymaking by inducing the EU legislators to rely upon sufficient knowledge before they exercise their discretion. ${ }^{65}$ This will in turn reinforce legal legitimacy as adherence to the court-imposed procedural requirements will serve as a check that the legislative outcome is in conformity with the Treaty mandate. The aspiration of procedural review is, thus, ultimately, to restore integrity in the making of EU legislation. $^{66}$

\section{Setting the framework for a general standard of review and test for legality of EU legislation}

This section develops, on the basis of the procedural review framework suggested in section 3 a more concrete benchmark which the Court should use to review the legality of EU legislation.

\section{The Court of Justice's track record in procedural review}

The following examines the Court's leading judgments on process-based review ${ }^{67}$, in particular with reference to the principles in Article 5 TEU. ${ }^{68}$

\footnotetext{
${ }^{62}$ See Case 24/62 Germany v Commission [1963] ECR 131, 69; Joined cases C-154/04 and 155/04 Alliance for Natural Health and Others (n 12), para 133; Scott and Sturm (n 15)572.

${ }^{63}$ Legal legitimacy depends on adherence to rules and suggests that decision of a public body is illegitimate if it transgresses some norm itself considered authoritative when it exercises its powers; see Fallon (n 60).

${ }^{64}$ See Thomas Poole, 'Legitimacy, Rights and Judicial Review' (2005) 25 Oxford Journal of Legal Studies 697, 713-717, 722, 725; Hammond and Markell (n 40) 316, 321-326.

${ }^{65}$ See Scott and Sturm (n 15) 570-571, 582-583; Mattias Kumm, 'The Idea of Socratic Contestation and the Right to Justification: The Point of Rights based Proportionality Review' (2010) 4 Law and Ethics of Human Rights 142, 153, 160-164.

${ }^{66}$ See Poole (n 64) 719, 724. See Ronald Dworkin, Law's Empire (Harvard University Press, 1986) 176-276 for an examination of the concept of 'integrity' in the law.

${ }^{67}$ See Alberto Alemanno, 'Regulatory Impact Assessment and European Courts: When Ex Ante Evaluation Meets Ex Post Judicial Control' (2011) 17 European Public Law 485, 499-503; Lenaerts, 'Process-Oriented Review' (n 32), 4-10; Schütze (n 17), 255-256.

${ }^{68}$ There are other intriguing cases on intense procedural review such as Case C-92/09 Volker und Martin Schecke and Eifert [2010] ECR I-11063 and Case C-236/09 Association belge des Consommateurs Test-Achats
} 
A review of the case law shows some common trends and development. Germany $v$ Parliament and Council ${ }^{69}$ suggested that the Court may not be willing to enforce procedural subsidiarity. In this case, the Court of Justice accepted that the Deposit Guarantee Directive complied with subsidiarity whilst the principle was not even mentioned in the preamble to the legislation. The Court even went quite some way to help the EU legislator to defend compliance with subsidiarity by indicating in the judgment those preambles which would support that EU action provided added value with regard to the regulation of deposit guarantee schemes. ${ }^{70}$ The Court's feeble stance on procedural subsidiarity has, however, been confirmed by subsequent case law. ${ }^{71}$

There are, nevertheless, single Court judgments which show a more aggressive stance on procedural review. ${ }^{72}$ Spain $v$ Council $^{73}$, which concerned a proportionality challenge to a regulation on a new cotton support scheme, ${ }^{74}$ laid down high informational requirements on the Union legislator. The Court of Justice applied a stringent procedural test ${ }^{75}$ and quashed the contested regulation on the basis of the Commission's failure to take into account all 'relevant information' pertaining to the situation and its failure to produce and present clearly the 'basic facts' which had to be taken into account as the basis of the contested regulation. ${ }^{76}$

Vodafone, concerned with a challenge to the EU roaming regulation, was the next important judgment on procedural review. In this case the Court clearly articulated a process-based approach to competence review by explicitly relying for the first time on the impact assessment and explanatory memorandum when examining the legality of an EU policy measure. ${ }^{77}$ The Court did, however, not entertain intense process-based review according to

and Others [2011] ECR I-00773 concerned with procedural review and fundamental rights. Whilst these judgments potentially may have implications for the general allocation of powers between the Member States and the EU they cannot be characterised as 'competence disputes' which is the main focus of this article.

${ }^{69}$ See Case C-233/94 Germany v Parliament and Council (n 12).

${ }^{70}$ Ibid paras 27-28.

${ }^{71}$ See Case C-377/98 The Netherlands v Parliament and Council (n 9), para 33, Case C-547/14 Philip Morris Brands and Others (n 9), paras 225 -226 for equally feeble application of procedural subsidiarity.

${ }^{72}$ See also the fundamental rights case law mentioned in $\mathrm{n} 68$.

${ }^{73}$ Case C- 310/04 Spain v Council (n 31).

${ }^{74}$ Council Regulation (EC) No 1782/2003 of 29 September 2003 establishing common rules for direct support schemes under the common agricultural policy and establishing certain support schemes for farmers and amending Regulations (EEC) No 2019/93, (EC) No 1452/2001, (EC) No 1453/2001, (EC) No 1454/2001, (EC) No 1868/94, (EC) No 1251/1999, (EC) No 1254/1999, (EC) No 1673/2000, (EEC) No 2358/71 and (EC) No 2529/2001 [2003] OJ 2003 L 270/1, inserted by Article 1(20) of Council Regulation (EC) No 864/2004 of 29 April 2004 [2004] OJ 2004 L 161/48 ('the Regulation').

${ }^{75}$ The case is discussed in detail below in section 4 (B) - (D).

${ }^{76}$ Case C- 310/04 Spain v Council (n 31), paras 122-135

${ }^{77}$ See Xavier Groussout and Sanja Bogojevic, ' Subsidiarity as a Procedural Safeguard of Federalism' in Loïc Azoulai, The Question of Competence in the European Union (Oxford University Press, 2014) 246, 252 for this 
the standard of 'relevant circumstances' suggested by Spain $v$ Council. ${ }^{78}$ Both in relation to its proportionality assessment and the review of the Roaming Regulation's conformity to Article 114 TFEU (which was the chosen legal basis for the measure) the Court employed the legislative background documents primarily to confirm that the EU legislator's choices as to the intensity and scope of the measure (covering both retail and wholesale charges) were justified. ${ }^{79}$ With regard to the analysis of Article 114 TFEU, the Court confirmed the Commission's contention that unless the Union intervened, there was a risk that divergent national measures would be adopted which would lead to distortion of the EU roaming market. $^{80}$

Afton Chemical, decided only one month after Vodafone, also contain important guidance from the Court on its approach to procedural review. Afton Chemical was a case concerned with a challenge to a directive on the specification of petrol, diesel and gas-oil. ${ }^{81}$ The Court referred in the case to the test in Spain $v$ Council of 'relevant circumstances ${ }^{82}$ but adopted a weak procedural approach to proportionality review. The problem in Afton Chemical was that the EU legislator had imposed new limits on the use of $\mathrm{MMT}^{83}$ in the final directive without any clear scientific basis for this limit or any explanation for why it had been included in the directive but not in the original proposal. The Court, however, held that the validity of EU legislation was not dependent on compliance with the underlying impact assessment, nor was there any requirement that deviation from the impact assessment is explained. This was according to the Court because the EU legislator under the ordinary decision-procedure was entitled to make amendments to the impact assessment and the original proposal. ${ }^{84}$

Whilst there are signs in the case law that the Court of Justice has gradually becoming engaged in a more 'process-based review', a modest reading suggest that these efforts should perhaps not be characterized as a success (with the exception of Spain v Council). There are,

observation. The Court referred to the impact assessments and explanatory memorandum in no less than 8 paragraphs: See Case C-58/08, Vodafone and Others (n 9), paras 39, 43, 45, 55, 58, 59, 63, 65.

${ }^{78}$ See Case C-310/04 Spain v Council (n 31), para 122.

${ }^{79}$ See Case C-58/08, Vodafone (n 9), paras 68-69; Martin Brenncke, 'Case note on European Court of Justice, C-58/08, Vodafone Ltd and Others v Secretary of State for Business, Enterprise and Re' (2010) 47 Common

Market Law Review 1793, 1809-1810.

${ }^{80}$ See Brenncke (n 79), 1801.

${ }^{81}$ See Directive 2009/30/EC of the European Parliament and of the Council of 23 April 2009 amending Directive 98/70/EC as regards the specification of petrol, diesel and gas-oil and introducing a mechanism to monitor and reduce greenhouse gas emissions and amending Council Directive 1999/32/EC as regards the specification of fuel used by inland waterway vessels and repealing Directive 93/12/EEC [2009] OJ 2009 L 140/ 88, Article 1(8).

${ }^{82}$ See Case C-343/09 Afton Chemical [2010] ECR I-07027, para 34.

${ }^{83}$ Methylcyclopentadienyl manganese tricarbonyl; see Directive 2009/30/EC (n 81), recital 35.

${ }^{84}$ Case C-343/09 Afton Chemical (n 82), paras 30 36-42, 56-69. 
although Vodafone witnessed more intense procedural review, fairly strong indications in the case-law that the Court's threshold for compliance with informational requirements has been fixed at an insufficiently low level. Germany $v$ Parliament and Council illustrates the extreme position of non-existing procedural enforcement of subsidiarity (similar to Phillip Morris) whilst Afton Chemical shows a very deferential procedural review by accepting deviations from the impact assessment. If we compare the Court's application of procedural review to the definition proposed in this article, it seems that the Court's procedural enquiry is limited to considering whether the EU legislator has stated a justification and not whether this justification is coherent with the grounds for exercising the competence under the relevant competence-conferring provision. Neither does the Court examine, ${ }^{85}$ whether the reasoning advanced for exercising the competence is supported by any evidence.

This turns us to the scope of procedural review. This section gave examples of procedural review in relation to all the constitutional principles in Article 5 TEU. It is argued that the Court should not, although most procedural review cases has been concerned with proportionality ${ }^{86}$, circumscribe procedural review to this plea but also use this form of review to also examine conferral and subsidiarity. ${ }^{87}$ There is no a priori rationale for limiting review to proportionality as it appears that the concerns of vague conceptual scope and institutional considerations apply equally to subsidiarity and conferral. ${ }^{88}$ As seen from the discussion here it is furthermore clear that the Court of Justice is willing to apply a form of procedural review also with regard to subsidiarity (Netherlands v Parliament and Council, Phillip Morris) and conferral (Vodafone, Phillip Morris), albeit not in the form advanced in this article. Experience from the US shows further evidence for the contention that process-based review can be used generally to enforce the constitutional order of competences. ${ }^{89}$ judicial review

This section develops, on the basis of the procedural review framework suggested in section 3, a more concrete benchmark which the Court should use to review the legality of EU legislation. Whilst the intense test in Spain v Council of 'relevant circumstances' has not, as

\footnotetext{
${ }^{85}$ See below section $4(\mathrm{E})$.

${ }^{86}$ Case C- 310/04 Spain v Council (n 31); Case C-58/08 Vodafone (n 9); Case C-343/09 Afton Chemical (n 82).

${ }^{87}$ See Craig, EU Administrative Law (n 28) 389-90; Scott and Sturm (n 15) 570-75.

${ }^{88}$ See above section 2.

${ }^{89}$ See in particular United States v. Lopez, 514 U.S. 549 (1995); United States v Morrisson 529 U.S. 598 (2000) which are seminal judgments on the scope of the Commerce Clause- the US equivalent of Article 114 TFEU.
} 
suggested above, been used consistently in relation to review of broad EU policy schemes ${ }^{90}$ this section argues that this judgment should be used as a benchmark for judicial review.

As we know from above, in this case, Spain challenged a Council regulation on new support schemes for cotton on the basis that it infringed the proportionality principle by not taking into account relevant information when deciding on the specific amount of aid granted under this scheme. The Court underlined, as regards judicial review of the principle of proportionality, the wide discretion enjoyed by the Union legislature in the field of the Common Agricultural Policy and that a measure adopted in this field could only be affected if the measure was manifestly inappropriate in terms of the objective which the EU institution is seeking to pursue and if the institution has manifestly exceeded the limits of its discretion. ${ }^{91}$ Up to this point, the Court simply followed its standard case law on review of proportionality within the sphere of broad EU policies. However, the Court dramatically changed this course of reasoning in paragraph 122 and 123 by imposing a new standard and test of review:

'However even though [such] judicial review of [proportionality] is of limited scope, it requires that the Community institutions which have adopted the act in question must be able to show before the Court that in adopting the act they actually exercised their discretion, which presupposes the taking into consideration of all the relevant factors and circumstances of the situation the act was intended to regulate. It follows that the institutions must at the very least be able to produce and set out clearly and unequivocally the basic facts which had to be taken into account as the basis of the contested measures of the act and on which the exercise of their discretion depended. ${ }^{92}$

On the basis of these principles, the Court proceeded to annul the regulation. The Court noted that the Commission had failed to include certain labour costs in the study of the foreseeable profitability of cotton growing under the new scheme. The Court emphasised that labour costs was a relevant factor for the purposes of calculating the production costs of cotton and the foreseeable profitability of that crop. The Court also found that the potential effects of the reform on the economic situation of the ginning undertakings- whilst being a 'basic factor' to be taken into account- were not examined. The Court recognised that cotton production is not economically possible without the presence of such undertakings operating under sustainable conditions, since cotton has little commercial value before being processed and cannot be

\footnotetext{
${ }^{90}$ See Case C-58/08 Vodafone (n 9); Case C-176/09 Luxembourg v Parliament and Council (n 11).

${ }^{91}$ See Case C-310/04 Spain v Council (n 31), paras 96-99, 104-105.

${ }^{92}$ ibid, paras 120-123.
} 
transported over long distances. Given that the Commission had been unable to show that it had actually exercised its discretion by taking into account all the relevant circumstances, the Court concluded that there was a breach of the principle of proportionality. ${ }^{93}$

C

\section{Analysis- why does Spain v Council provide an appropriate standard of review?}

Commentators have argued that Spain v Council marks a clear evolution towards greater intensity in the judicial review of facts and in the application of procedural proportionality and that the standard of legality proposed by this case is consistent with the Court of Justice's earlier jurisprudence on review of administrative decisions. ${ }^{94}$ While Spain v Council appears to be an important judgment of principle, it is contestable whether this case can be interpreted as evidence for a transformation from deferential review to intense judicial examination of facts in relation to EU legislation. There are, as mentioned above, ${ }^{95}$ no cases on competence review, post-Spain $v$ Council, which have followed the intensity of review suggested by that judgment. Nor is there any clear basis in the Court's case law on review in the field of the common policies prior to Spain v Council under which the Court's propositions in that judgment could be grounded. ${ }^{96}$ Furthermore, although the factual review by the Court of Justice in Spain v Council was reminiscent of the Court of First Instance's (CFI $\left.{ }^{97}\right)$ strict factual review in Tetra Laval and Pfizer, the last-mentioned judgments must be distinguished from Spain v Council. The CFI's extremely searching enquiry in Pfizer ${ }^{98}$ and Tetra Laval, ${ }^{99}$ although like Spain $v$ Council phrased in terms of 'manifest error' and 'manifestly inappropriate', was prompted by the fact that those judgments were, in principle, related to individual decisions. Such decisions are generally subject to a highly intense review by the EU courts. ${ }^{100}$ Although the regulation ${ }^{101}$ in Pfizer was formally of a general nature, its effect

\footnotetext{
${ }^{93}$ ibid, paras 102, 131-135.

${ }^{94}$ See Xavier Groussout, 'Judgment C-310/04, Kingdom of Spain v Council of the European Union' (2007) 44 Common Market Law Review 761, 777-782; Alemanno, 'Regulatory Impact Assessments and European Courts' (n 67) 501.

${ }^{95}$ See $\mathrm{n} 68$ for reference to Court judgments on fundamental rights reflecting high intensity review.

${ }^{96}$ See, however, Case C-189/01 Jippes v Minister van Landbouw, Natuurbeheer en Visserij [2001] ECR I-5689, paras 80-101, 113-122, for an exception of more searching proportionality review.

${ }^{97}$ Now referred to as the 'General Court'.

${ }^{98}$ See Case T-13/99 Pfizer Animal Health v Council [2002] ECR II-03305, paras 166-170.

${ }^{99}$ See Case T-5/02 Tetra Laval v Commission [2002] ECR II-04381, paras 119, 140-141, 197-199, 224, 283 , 308, 335-336; Case C-12/03 P Commission v Tetra Laval [2005] ECR I-00987, paras 38-39.

${ }^{100}$ See Craig, EU Administrative Law (n 28) 416-424, 427-430, 438-439.

${ }^{101}$ Council Regulation (EC) No 2821/98 of 17 December 1998 amending, as regards withdrawal of the authorisation of certain antibiotics, Directive 70/524/EEC concerning additives in feeding stuffs [1998] OJ 1998 L 351/4.
} 
had the nature of a decision by withdrawing Pfizer's authorisation to market virginiamycin and since Pfizer was the only company having such an authorisation. The act was thus of 'direct' and 'individual' concern to Pfizer'. ${ }^{102}$ Tetra Laval on the other hand was concerned with a Commission decision prohibiting a prospective merger. The fact that this decision immediately affected the rights of Tetra Laval required a full judicial review of the Commission's decision both in relation to law and facts. ${ }^{103}$ Given the distinction in the EU courts' case law between the nature of review in situations involving administrative decisions and general legislative acts, it seems that Spain v Council was an exception to the rule that review in the field of the common policies is of low intensity

Notwithstanding this, it is argued that the benchmark suggested by Spain v Council provides an appropriate yardstick for showing how the Court of Justice should review EU legislation in vertical competence disputes. The Court's standard requiring the objectives of the legislation to be substantiated is an appropriate 'middle-way' solution between full substantive review of facts and complete surrender to the political authority of the EU legislator. ${ }^{104}$ The Court's burden of proof, (deviating from the main rule that applicants challenging general EU legislative acts must demonstrate the measure to be disproportionate), requiring the $\mathrm{EU}$ institutions to show that it had exercised its discretion contributed in making the standard of review credible. ${ }^{105}$ Thereto, it is clear that the rigour of the Court's review was appropriate to implement the legality standard. The strict intensity entailed that the Court did not accept the assertions made by the Commission but examined independently whether it had taken into account 'relevant information'. 106

\section{Spain v Council expresses a general standard of 'adequate reasoning' and 'relevant information'}

If we generalize the Court's propositions from Spain v Council, it is contended that this case suggests a standard of legality both in relation to reasoning and evidence. The benchmark is

\footnotetext{
${ }^{102}$ See Art 263(3) TFEU; Case T-13/99 Pfizer Animal Health v Council (n 98) paras 42, 81-87, 89-106, 171172.

${ }^{103}$ See Case T-5/02 Tetra Laval v Commission, (n 99) paras 89-90.

${ }^{104}$ See Lenaerts, 'Process-Oriented Review' (n 32) 7-9, 15.

${ }^{105}$ See Case 331/88 The Queen v Ministry of Agriculture, Fisheries and Food, ex parte FEDESA and Others [1990] ECR I-04023, para 14; Case C-491/01 British American Tobacco (Investments) and Imperial Tobacco (n 9) paras 123, 130, 140.

${ }^{106}$ See Case C- 310/04 Spain v Council (n 31), paras 110, 113-119, 131, 132-133.
} 
whether the EU legislator provided for 'adequate reasoning' and took into account 'relevant circumstances' when it exercised its legislative competence.

The expression 'relevant information' used by the Court connotes implicitly a requirement in relation to the quality of the reasoning. The Court of Justice was not only critical of the fact that the Commission had failed to include labour costs and perform a socio-impact study. It also condemned the fact that the Commission had been unable to explain why an impact study was not necessary and why labour costs were not included in the assessment of profitability. ${ }^{107}$ The Court's assessment of the profitability study is instructive. The Council, basing its argument on the reform's budgetary neutrality, contended that the profitability study should also take into account the income deriving from the single payment. Since the sum of the coupled and decoupled aid under the new scheme was equivalent to the total amount of the indirect aid granted under the previous scheme, the profitability of cotton growing could not be doubted. The single payment should not be taken into account according to the Court as it is granted independently of the crop chosen, even if the farmer decides not to produce anything. The budgetary neutrality of the reform was furthermore of no relevance for assessing whether in the future farmers will abandon cotton growing. ${ }^{108}$ The standard of 'relevant circumstances' furthermore entails a requirement with regard to the quality of the evidence. In Spain v Council, the Court itself decided what constituted 'relevant' information for deciding upon the amount of aid. The Court found that fixed labour costs should have been included in the profitability assessment under the new support scheme and that the effect of the reform on the situation of the ginning undertakings was also 'relevant information' without which the Commission could not exercise its discretion. ${ }^{109}$

\section{$\mathbf{E}$}

\section{A proposed standard for review and test for legality}

The proposed benchmark suggests a two-step examination of legality of EU measures. The first part of the enquiry implies that the Court of Justice should look 'beyond the preamble of the measure' when examining the adequacy of the reasoning and consider whether the reasons stated by the EU legislator in the 'legislative background documents' ${ }^{110}$ are pertinent for assessing compliance with the principles in Article 5 TEU. The test to assess whether the standard of 'adequate reasoning' has been conformed to is the following. The EU legislator

\footnotetext{
${ }^{107}$ See Case C-310/04 Spain v Council (n 31), paras 105-111, 116-118, 124-129, 131.

${ }^{108}$ Ibid, paras 108-111.

109 ibid, paras 112-118, 126, 128-132.

${ }^{110}$ See $\mathrm{n} 40$ for this expression.
} 
must offer at least one justification, which is by itself sufficiently compelling to justify compliance with the relevant principle or rule whose observance the institutions must ensure. $^{111}$ The reference point for the adequacy of the reasoning is the substantive justifications for the exercise of EU competences, as this has been generally recognized by the EU law literature and/or the Court's case-law. One example is if the EU legislator employs an argument based on distortions of competition to justify the 'essentiality' of criminal sanctions under Article 83(2) TFEU. ${ }^{112}$ Since the question of 'essentiality' of criminal laws under this provision is only concerned with a comparison of criminal laws with other sanctions, it seems incoherent to mingle internal market considerations into this assessment. ${ }^{113}$ Such considerations are not 'relevant factors' ${ }^{114}$. 'Adequate' reasoning does not, however, require that the EU legislator offered the most appropriate reasoning for defending compliance with the precepts of the Treaties. ${ }^{115}$ It is sufficient that the reasoning is 'adequate' to support adherence to the underlying Treaty condition or principle. ${ }^{116}$

The second limb of the test considers whether the reasons are substantiated. In order to pass this part of the test, the EU legislator needs to show that the rationale given for the legislative act (which in itself justified the EU legislator's adherence to the relevant EU rule or principle) is supported by sufficient and relevant evidence. ${ }^{117}$

This standard entails requirements both in relation to the quantity and quality of the evidence. First, in order to prove a statement, it is necessary to refer to more than one source. If, for example, the evidence for a theoretically plausible claim consists of a reference to only one study or one scholarly article, this would be insufficient. ${ }^{118}$ The Court ought furthermore to examine whether the evidence in the legislative background documents is 'adequate' for

\footnotetext{
${ }^{111}$ See Joined cases C-584/10 P, C-593/10 P and C-595/10 P Commission and others v Kadi (Court of Justice, 18 July 2013, 'Kadi II' ), para 130.

${ }^{112}$ See for example Commission,' Proposal for a Directive of the European Parliament and of the Council on criminal sanctions for insider dealing and market manipulation', COM (2011) 654 final, 3, 5, recital 7.

${ }^{113}$ See Petter Asp, The Substantive Criminal Law Competence of the EU-Towards an Area of Freedom, Security \& Justice - Part 1 (Jure, 2013), 130-132; Peter Whelan, 'Contemplating the Future: Personal Criminal Sanctions for Infringement of EC Competition Law' (2008) 19 King's Law Journal 364, 370-371

${ }^{114}$ Case C-310/04 Spain v Council (n 31), para 122.

${ }^{115}$ See a similar formula for the assessment of proportionality; Case C-58/08 Vodafone (n 9), para 52.

${ }^{116}$ See the discussion above in section 3 of the risk that the Court's review of the legislator's reasoning is transformed into substantive review.

${ }^{117}$ See Joined cases C-584/10 P, C-593/10 P and C-595/10 P Commission and others v Kadi (n 111), paras 119 and 124, 130. This standard for the 'evidence 'requirement is also supported by the Court's ruling in Case C12/03 P Commission v Tetra Laval (n 99), para 39; 'Not only must the Community Courts, inter alia, establish whether the evidence relied on is factually accurate, reliable and consistent but also whether that evidence contains all the information which must be taken into account in order to assess a complex situation and whether it is capable of substantiating the conclusions drawn from it.'

${ }^{118}$ See Alemanno, 'evidence-based judicial reflex' (n 30) 333-335, 338.
} 
substantiating the exercise of the legislative competence. ${ }^{119}$ Taking again the example of EU criminal law competence it is suggested that if the EU legislator uses evidence concerning 'distortions of competition' to justify the 'essentiality' of criminal sanctions it would also fail to conform to the standard of 'relevant evidence'. This is because the 'essentiality' of criminal sanctions can only be justified on the basis of evidence showing that criminal sanctions are a greater deterrent than other sanctions. ${ }^{120}$ The evidence should finally be 'reliable'. Insignificant evidence or evidence of low credibility (such as hearsay evidence) cannot be used to support a statement. This means that the evidence needs to be in the nature of statistical studies, policy studies or scientific articles which provide more serious support for an argument. $^{121}$

Rationale and issues with the test

The following considers the purpose of the test. The test is not a substantive one intended to limit EU action or finding out the proper level of action. ${ }^{122}$ The test is functional to ensure that the political discretion granted to EU an institution is exercised in a rational manner and that the Court is empowered to review the exercise of EU competences. ${ }^{123}$ Since the proposed test requires reasons and evidence to always be given for the exercise of competences, it is more likely that the Court will be able to fulfil its task of monitoring that the law of the Treaties is observed. ${ }^{124}$ The pragmatic rationale for the test is that it is predictable by clearly articulating under which circumstances intervention is justified. ${ }^{125}$ The reference point here is whether one of the reasons relied upon in a legislative act constitutes sufficient basis to support that act and is substantiated by relevant evidence. ${ }^{126}$

The main critique against this test of legality is probably that the proposed requirement on the EU legislator of offering 'one cogent reason supported with sufficient evidence' is borrowed

\footnotetext{
${ }^{119}$ See joined cases C-584/10 P, C-593/10 P and C-595/10 P Commission and others $v$ Kadi (n 111) paras 118$119,124$.

${ }^{120}$ See $\mathrm{n} 113$ for reference to literature supporting this point.

${ }^{121}$ See joined cases C-584/10 P, C-593/10 P and C-595/10 P Commission and others $v$ Kadi (n 111), paras 151162 for the application of the evidence standard. What the Court does is to monitor whether any of the reasons submitted, which can support the decision, is supported by sufficient evidence (para 162). This is the same method that the Court should apply in cases of review of EU legislation.

${ }^{122}$ See Art 5 TEU.

${ }^{123}$ See Scott and Sturm (n 15) 592-593. This test is however wider than 'rationality' review used in some jurisdictions which seem, within the realm of EU law, to be confined to questions primarily addressed by proportionality review, see further Paul Craig, 'Judicial Review and Questions of Law: A Comparative Perspective', Legal Research Paper Series No 56/2009 October 2009, 7-8, 11-12, 21-22, 26.

${ }^{124}$ See Art 19 TEU; Shapiro (n 39), 218-220.

${ }^{125}$ See Craig, EU Administrative Law (n 28) 434-36.

${ }^{126}$ See above section $4 \mathrm{E}$.
} 
from the Court of Justice's case law on fundamental rights and targeted sanctions ${ }^{127}$ and its case law in the field of competition law/risk regulation ${ }^{128}$ and that the concerns underlying this standard of review may not be applicable in the field of common policies. In the context of targeted sanctions, the strict interpretation of 'manifest error' has partly been driven by the limitations imposed on courts reviewing the Security Council resolutions that form the basis for EU regulations freezing assets of particular individuals and the fact those decisions have substantive negative effects for targeted individuals. ${ }^{129}$ In relation to competition law, the strict review of 'manifest error' have been driven by the criticisms voiced about the role of the Commission as prosecutor, judge, and jury, and the fact that competition law enforcement is intrinsically concerned with potential infringements of the fundamental rights for the accused. $^{130}$

In this regard it is important to underline that Court of Justice's standard of review and intensity is not dependent upon whether review is undertaken in a specific area such as fundamental rights, internal market or competition law. The key rationale for stringent review in the discussed fundamental rights ${ }^{131}$ and competition law and risk/regulation cases is related to the fact that these cases were concerned with 'individual decisions' or decisions of a similar nature. It is clear that the Union Courts in such cases are tasked with reviewing both the factual and legal assessment of the administrative agency or legislator, i.e. the Commission. Although the freezing of assets cases were concerned with regulations those acts were in fact in the nature of individual decisions rather than general legislative acts. In Kadi II, Tetra Laval and Pfizer, it is clear that there were targeted individuals and firms that were the subject of the decision/regulation. When the EU legislator rather acts as an executive than a general legislature less deference is justified because the effects of annulment are less draconic, because strict review of individual decisions does not encroach upon the EU legislator's political discretion and because individuals must be protected against discretionary interferences with their fundamental freedoms. ${ }^{132}$ In relation to judicial review of the EU legislator's discretionary policy choices, other considerations are relevant. It might be argued

\footnotetext{
${ }^{127}$ See for example Joined cases C-584/10 P, C-593/10 P and C-595/10 P Commission and others $v$ Kadi (n 111), paras119, 121, 122, 130; Case T-392/11 Iran Transfo v Council (Court of First Instance, 16 May 2013), paras 34, 44;Case C-550/09 E and $F$ [2010] ECR I-06213, para 57.

${ }^{128}$ See the cases referred to in nn 98-99.

${ }^{129}$ See $\mathrm{n} 127$ for reference to the relevant case law.

${ }^{130}$ See Craig, EU Administrative Law (n 28) 438-439.

${ }^{131}$ Where EU fundamental rights have been used to challenge common policies, review has traditionally tended to be deferential: see eg Case C-491/01 British American Tobacco (n 9) paras 149-152; Cases C-184 and 223/02 Spain and Finland $v$ European Parliament and Council [2004] ECR I-7789.

${ }^{132}$ See above section 4 (C).
} 
that scrutiny in the context of broad EU common policies should be very deferential because the facts are complex, since the EU legislator undertakes discretionary policy choices and because the EU legislature has to reconcile divergent interests when making such policies. In these cases, the Court is also normally tasked with reviewing a broad piece of framework legislation, which may have been subject to cumbersome negotiations between the different EU institutions, and that are envisaged to generally approximate Member States' legislation in a certain field. It is clear that the Court may less willing to frustrate polices which have come at such a high cost. ${ }^{133}$

The division in the case law between review of general legislative acts and acts being primarily addressed to certain individuals thus suggest that there must be a justification for transferring the intense test derived from the Court's case law in Tetra Laval and Kadi II to the field of the common policies. ${ }^{134}$ It is, however, suggested that a distinction must be made between the 'test' for legality and the 'intensity' of the review. The argument here does not suggest that the Court of Justice should review with the same intensity general EU legislative acts as it does administrative decisions. 'Manifest error' review in the style of Tetra Laval and Kadi II is strict substantive review that is used when the Court examine individual administrative decisions. Such review entails a de novo assessment of the legal and factual assessment made by the administrative agency. ${ }^{135}$ Such a review is different from review of EU legislation in vertical competence disputes which cannot be as intensive as this would upset the principle of institutional balance. ${ }^{136}$ It is only claimed here that the test, i.e. whether the EU legislator offered at least one compelling rationale for exercising competence and whether that reason was supported with 'relevant' evidence, should be analogous to the one adopted for review of administrative decisions. ${ }^{137}$

This being so, it is a legitimate concern that the proposed test may encroach on the EU legislator's discretion and entail substitution of judgment. If the Court would apply the test as proposed here, there would be a risk that the Court exceeds the limits of its 'authority' and 'legitimacy' as derived from the Treaties. Whether this criticism can be sustained depends on 'how' the test, if it ever finds its way into the Court of Justice's jurisprudence, is applied by the Court. If the Court applies the proposed test with the same rigour as it has done in

\footnotetext{
${ }^{133}$ See Craig, EU Administrative Law (n 28) 437-438, 592-593.

${ }^{134}$ This division seems to be generally accepted for courts engaged in judicial review: see Alison L Young,' In Defence of Due Deference', (2009) 72 Modern Law Review 554, 556-559.

${ }^{135}$ See Craig, EU Administrative Law (n 28) 434-436.

${ }^{136}$ See Art 13(2) TEU.

${ }^{137}$ See Coenen (n 30), 2887-2888.
} 
fundamental rights and competition law/risk regulation cases and substantively re-examines the EU legislator's political assessment ${ }^{138}$ this would entail an encroachment on the EU legislator's discretion. Then, the Court should face criticism. If the Court, however, reviews legislation according to the guidelines provided above, the concern that the test would lead to substitution of judgment will be undermined. ${ }^{139}$

Finally, whilst an evidence criterion in cases of competence review has not yet been fully embraced by the Court of Justice, there are implicit foundations in the case-law to construct such a requirement. This suggests that it would not be such a bold move for the Court to apply the proposed test for legality. As we saw above, there was a requirement imposed in Spain $v$ Council, that compliance with the proportionality principle needed to be defended by specific figures and evidence. ${ }^{140}$ More importantly, it is argued that the Tobacco Advertising judgment indicates a firm evidence criterion for the EU legislature to fulfil when legislating under Article 114 TFEU. The Court stated in this judgment that it is not sufficient to show 'hypothetical' risks of obstacles. The EU legislator must thus show that disparities give rise to concrete obstacles or that it is likely that such obstacles will arise. The Court of Justice also clarified that the EU legislator cannot rely on incidental or potential distortions as justifications for harmonization- instead it must demonstrate that the distortions of competition at issue are 'appreciable'. ${ }^{141}$

Furthermore, although cases such as Test Achat and Volker und Martin Schecke on fundamental rights cannot be used as evidence for a transformation to stricter 'competence review', it appears that the intense review in Spain $v$ Council was endorsed in those judgements. In both these cases, which focused on the EU legislator's justification for infringing the right to personal data (Volker und Martin Schecke) ${ }^{142}$ and the right to equality (Test Achat), ${ }^{143}$ the Court made a strict procedural enquiry of the EU legislator's justification. The Court considered in Volker und Schenke that the EU legislator had not done their preparatory work properly by failing to consider alternatives which interfered less with the fundamental rights of the beneficiaries concerned. In Test Achat the Court condemned the EU legislator because there was a contradiction between the challenged provision (which entailed

\footnotetext{
${ }^{138}$ See A G Toth' Is Subsidiarity justiciable?' (1994) 19 European Law Review 269, 283-284, for an argument on how the application of subsidiarity may result in substitution of judgment.

${ }^{139}$ See Craig, EU Administrative Law (n 28) 433-34.

${ }^{140}$ See above section 4 (B)-(D).

${ }^{141}$ See Case C-376/98 Germany v European Parliament and Council (Tobacco Advertising) [2000] ECR I-8419, para 84, 86, 98-99, 106-107.

${ }^{142}$ See Case C-92/09 Volker und Martin Schecke and Eifert (n 68) paras 65-89.

${ }^{143}$ See Case C-236/09 Association belge des Consommateurs Test-Achats and Others (n 68) see paras 25-32.
} 
an extension for Member States to apply discriminatory premiums to male and female beneficiaries) and the objectives pursued by the contested EU act which pursued the principle of non-discrimination. There is no principal reason why the Court cannot use its approach in these fundamental right cases to also review challenges based on Article 5 TEU. ${ }^{144}$

Whilst it is not possible to comprehensively discuss here whether the judicial enforcement of federal values should be as intense as rights-based review, the argument here is sympathetic to Lynn Baker and Ernest Young's compelling narrative on 'double standards'. They suggest that there are no normative justifications for courts to discriminate between enforcement of human rights and implementation of federal values. On this basis, discrete enforcement of certain values of the EU constitutional order should be rejected on the ground that the values protected by that order should be of equal importance. It thereto appears that the recognition of limits on EU regulatory authority and protection of state rights ultimately will increase the sphere of individual autonomy (which is one of the key rationales for rights-based review). Member States can act as a strong safeguard of individual freedoms since they are capable of imposing more serious obstacles to intrusive governmental interferences than what individuals could achieve alone. ${ }^{145}$ Judicial scrutiny of EU criminal law legislation under Article 83(2) TFEU illustrates this point. It is arguable that intense judicial review of the conditions in this provision, in particular the 'essentiality' condition, is justified by the fact that criminalization tend to encroach on the fundamental freedom of liberty. Thus, a strict enforcement of the balance of powers between the Member States and the EU within this context would surely have the implications that individuals will be protected from intrusions in their personal autonomy. ${ }^{146}$

Whilst the genesis of the proposed standard springs from Spain v Council and the concrete test is derived from the Court's manifest error review in Kadi II, it develops the Court of Justice's intensity further than the Court's current approach to review of EU legislation.

\footnotetext{
${ }^{144}$ See $\mathrm{n} 48$ for reference to literature supporting this proposition.

${ }^{145}$ Lynn A. Baker \& Ernest A. Young, 'Federalism and the Double Standard of Judicial Review', 51 (2001) Duke Law Journal 75, 133-62.

${ }^{146}$ See Maria Kaiafa-Gbandi, 'The Importance of Core Principles of Substantive Criminal Law for a European Criminal Policy Respecting Fundamental Rights and the Rule of Law' (2011) 1 European Criminal Law Review 7, 17-21; Sakari Melander, 'Ultima Ratio in European Criminal Law' (2013) 3 European Criminal Law Review $45,52$.
} 
It appears that the Court's current case law does not entail demanding informational demands on the Union legislator. The Court has never in its previous jurisprudence imposed any requirement to submit evidence for compliance with certain requirements of the Treaties such as 'quantitative' indicators in relation to subsidiarity or 'appreciable distortions to competition' in Article 114 TFEU. The Court seems to accept simple assertions of the EU institutions on the existence of effects or problems. In fact, it seems that the Court, instead of standing outside the legislative procedure, endeavours to support the EU legislator's case by seriously looking for any evidence and reasoning that can justify compliance with the precepts of the Treaties. ${ }^{147}$

The proposed test does not accept insufficient evidence for establishing compliance with Article 5 TEU. The Court must reverse its light test for judicial intervention and strike down legislation which contains assertions that are not justified by the facts of the case. Contrary to the Court's approach in Germany $v$ Council $^{148}$ and Swedish Match ${ }^{149}$, the suggested test does not accept mere reference to preambles as justification for legislation but requires references to evidence in legislative background documents. The Court must also consider, in contrast to cases such as Vodafone $e^{150}$ and Alliance Health ${ }^{151}$, whether the evidence is connected to the rationale for exercising the competence.

While this does not mean that a proper impact assessment is a requirement for legality, it implies, that the EU legislator must refer to empirical evidence, whether that be a scientific study, scholarly articles or statistics, to support the measure. ${ }^{152}$ Admittedly, it appears that the test as applied to proportionality review rarely will result in annulment of EU legislation. The intensity of the test, however, entails that the EU courts would have to inquire more in greater depth into the claim that the decision was 'manifestly inappropriate' as compared to the classical approach. ${ }^{153}$ Instead of simply clearing the Union legislator by noting that he has not crossed the barrier of 'manifestly inappropriate', the standard forces the Court to autonomously determine whether the EU legislator has supported his conclusions by relevant

\footnotetext{
${ }^{147}$ See Case C-491/01 British American Tobacco (Investments) and Imperial Tobacco (n 9), paras 68-73, 84-87, 124, 134-135, 181-184; Case C-380/03 Germany $v$ Parliament and Council [2006] ECR I-11573 paras 46-48, 62, 66, 85-86; Case C-301/06 Ireland v Parliament and Council [2009] ECR I-00593, paras 66-72, 83.

${ }^{148}$ See Case C-233/94 Germany v Parliament and Council (n 12) paras 26-28.

${ }^{149}$ See Case C-210/03 Swedish Match (n 9), paras 36-41.

${ }^{150}$ See Case C-58/08 Vodafone and Others (n 9) paras 38-47, 76-79.

${ }^{151}$ See Joined cases C-154/04 and 155/04 Alliance for Natural Health and Others (n 12), paras 35-40, 105-107.

152 See Alemanno, 'Regulatory Impact Assessments and European Courts' (n 67) 501.

${ }^{153}$ See the Court of Justice's case-law referred to in $\mathrm{n} 11$.
} 
evidence. ${ }^{154}$ The key distinction from the Court's current approach is thus that the proposal here asks the Court to be more intrusive when considering whether the necessary facts have been taken into account before exonerating the EU legislator.

\section{Conclusions and reflections}

The concluding part of this article contains a summary of the argument and reflections on the proposed model's consequences for the federal dimension of EU law.

The aim of this contribution was to examine the problems of judicial review within the context of enforcing the constitutional principles in Article 5 TEU. In particular, it queried how the Court of Justice, given the absence of appropriate legal criteria and institutional constraints, could develop a more intense form of judicial review in competence disputes. The main proposal for improving enforcement of conferral, subsidiarity and proportionality was to use a procedural type of review, requiring the Court to examine the EU legislator's reasoning and evidence for a legislative measure. A move for the Court to stronger substantive review was rejected with reference to institutional constraints in terms of legitimacy and competence. ${ }^{155}$ To some extent it appears that procedural review suffers from similar problems that are associated with substantive review. A procedural review is nevertheless less controversial in terms of institutional competence and democratic legitimacy than substantive review. Thereto, any disadvantages with a procedural form of review would be outweighed by the advantages of greater legitimacy in the EU decision-making procedure that such a review would entail. $^{156}$

The article subsequently developed on the basis of the Court's judgment in Spain v Council, a specific standard of review for all broad EU policy measures. This standard suggests that the EU legislator must offer 'adequate reasoning' and 'relevant evidence' for a proposed legislative measure in order for it to conform to the limits of the Treaties. ${ }^{157}$ To control whether the proposed standard of 'adequate reasoning' and 'relevant evidence' has been met, the article proposed on the basis of the Court's ruling in Kadi II an intrusive test of legality.

\footnotetext{
${ }^{154}$ See Case T-310/06 Hungary v Commission [2007] ECR II-4619, paras 144-167. Case T-126/99 Graphischer Maschinenbau GmbH v Commission [2002] ECR II-2427; Craig, EU Administrative Law (n 28), 425, 438-439, 442.

${ }^{155}$ See Bar- Siman-Tov, 'Semiprocedural Judicial Review' (n 30) 287-288; Craig, EU Administrative Law (n 28) 439-440.

${ }^{156}$ See Leczykiewicz (n 61), 12-13.

${ }^{157}$ See above section 4 (B) - (D).
} 
The EU legislator must articulate at least one justification, which in theory - i.e. in light of the relevant literature and the Court's case law - is sufficient as a basis for exercising the competence and substantiate this rationale by 'sufficient' and 'relevant' evidence. Such a demanding test was justified on the basis that it would push the EU legislator to prepare more evidence-based justification and ultimately restore confidence in the EU political procedure.

What are then the implications of the argument advanced in this article? It appears that the proposed model is likely to have bearings for the federal dimension of EU law: the relationship between the EU and its Member States. The suggested process-based test is intended to be employed in highly contested challenges to EU legislation on the basis of proportionality, subsidiarity and lack of 'competence'/incorrect legal basis. The Court's approach these principles have serious constitutional implications for the Union legal order by shaping the distribution of competences and by defining the standards for examining the legality of a Union act. ${ }^{158}$

Critics of the test may argue that it will negatively affect the process of EU integration by imposing too cumbersome limits on the discretion of the EU legislator. Strict judicial review of the exercise of EU competences would compromise the Union's capacity to act efficiently in order to fulfil the tasks of the Treaties and would impose significant costs reflected in inflexibility. They may also argue that the test will stretch the Court of Justice's institutional capacities and force it to become involved in deeply political and constitutional choices on the future of EU integration and that the Courts lacks the democratic credentials to make those choices. $^{159}$

There is force in this point as the proposed test may push the Court to the limits of its legitimacy and authority. However, counterintuitively, legitimacy may be the best argument for the Court to enforce the constitutional principles in Article 5 TEU more seriously after Lisbon. Infusing judicial review of EU legislation with greater force is, as argued above, not only a way of enhancing the accountability of the EU legislative procedure but also the legitimacy of the Court of Justice. ${ }^{160}$ The Court of Justice was created with the aim of providing an unbiased arbitrator to mediate between the interests of the EU and the Member

\footnotetext{
${ }^{158}$ See Case C-370/07 Commission v. Council [2009] ECR I-8917, paras 46-49; Armin Von Bogdandy and Jürgen Von Bast, 'The Federal Order of Competences' in Armin Von Bogdandy and Jürgen Bast, Principles of European Constitutional Law (Hart Publishing, 2009) 279, 301.

${ }^{159}$ See Azoulai (n 22) 2, 5-6; Weatherill, 'Limits to legislative harmonization' (n 3) 863.

${ }^{160}$ See above section 3 , text to nn 56-66.
} 
States. The Court's approach to date is however inadequate as a safeguard of federalism. ${ }^{161}$ The Court's weak stance in vertical competence litigation has not only failed to promote a culture of justification in the EU legislative process but also devalued Member State rights the observance of which the Court should ensure. If the Court continues on this path it will face legitimate criticism that it is failing in its task to ensure that the law of the Treaties are observed. ${ }^{162}$ To address these concerns the Court must change its current deferential approach and review the exercise of EU powers with more vigour. The Treaty of Lisbon also suggests that the Court should submit the exercise of the EU competences to stricter control. By providing for a special review procedure for national parliaments of EU legislation, ${ }^{163}$ by adopting a specific protocol on subsidiarity and proportionality, ${ }^{164}$ by adopting a new provision for the protection of the constitutional identity of Member States ${ }^{165}$ and by restating throughout the Treaties the importance of the principle of conferral ${ }^{166}$ the Member States has made a conscious decision to construct new limits to the exercise of EU powers. ${ }^{167}$

Finally, even if the strict procedural review advanced here ultimately imposes substantive limits on the exercise of Union competences, there are good reasons for the Court to enforce those constraints. The Court has indeed an important role as guarantor of the values of federalism- such as local experimentation and potential for innovation, efficiency, participatory democracy regulatory competition among jurisdictions, adaptation to local preferences, and governmental accountability to voters- in cases where the Union legislator fails to adhere to such values. ${ }^{168}$ It is evident that the Union political institutions take indications from the Court as to what values should be safeguarded. If the Court were to announce that the issue of federalism is entirely subject to the whims of politics, the Union political branches would not take these values seriously in their own deliberations. ${ }^{169}$ The Court of Justice is thereto tasked with ensuring the balance between Member States and the

\footnotetext{
161 See Roman Herzog and Lüder Gerken, 'Stoppt den Europäischen Gerichtshof', Frankfurter Allgemeine Zeitung, 8 September 2008; Gunnar Beck, 'The Court of Justice, legal reasoning, and the Pringle case: Law as continuation of politics by other means' (2014) 39 European Law Review 236, 238, 244.

${ }^{162}$ See Leczykiewicz (n 61) 4, 8, 12-13.

163 See Protocol (No 1) On the Role of National Parliaments in the European Union OJ [2010] C 83/203.

${ }^{164}$ See Protocol (No 2) On the Application of the Principles of Subsidiarity and Proportionality OJ [2010] C $83 / 206$.

165 See Art 4(2) TEU.

${ }^{166}$ In addition to Art 5(2) TEU, there are a number of other provisions which expressly or implicitly reinforce the principle of conferral: Art 1(1) TEU; Art 3(6) TEU; Art 4(1) TEU; Art 13(2) TEU; Art 48(6) TEU; Art 2(1) TFEU; Art 2(2) TFEU; Art 4(1) TFEU; Art 7 TFEU; Art 19 TFEU; Art 130 TFEU; Art 207(6) TFEU; Art 226 TFEU; Art 314(10) TFEU; Art 351(3) TFEU.

${ }^{167}$ See Azoulai (n 22) 10-11.

${ }^{168}$ See Bermann (n 26) 340-344; Kumm,' Constitutionalizing Subsidiarity (n 48) 518; Ernest A Young, 'Two Cheers for Process Federalism' (2001) 46 Villanova Law Review 1349, 1354, 1370-1374, 1387-88.

${ }^{169}$ See Young, 'Two Cheers' (n 168), 1391.
} 
Union as set down in the Treaties ${ }^{170}$ and to make each of these constitutive units responsible for the exercise of their own powers. ${ }^{171}$ The Court even stated this in Tobacco Advertising judgment that giving the EU legislator a general regulatory power under Article 114 TFEU would be contrary to the principle of conferral and absolve the Court from its duties under Article 19 TEU to uphold the law of the Treaties. ${ }^{172}$

Whilst recognizing that the Court also must impose some substantive limits on EU regulatory authority ${ }^{173}$, the core argument still is that the values of federalism are best implemented by a strict procedural approach according to the lines suggested above. While the EU political institutions may be trusted to resolve most substantive disputes about EU policy, the Court of Justice is responsible to police the system of political and institutional safeguards that the EU political process ordinarily rely on to resolve most problems. ${ }^{174}$ Ultimately, it is envisaged that a stringent process-based judicial review of the EU law-making process will help us in reinstating the balance of powers between Member States and the Union and enable the Court to better protect Member State autonomy against the risk of illegitimate EU centralization. ${ }^{175}$

While genuinely engaging in the enforcement of the EU federal order of competences is a difficult constitutional choice and implies that the Court must develop a stricter standard of review and become involved in fundamental political and social questions, it is argued that such a review is both necessary and legitimate to maintain the division of powers between the EU and its Member States. ${ }^{176}$ Unless the Court steps up this challenge, EU constitutional law would regrettably have to rely solely on political control as a safeguard of federalism in the EU.

\footnotetext{
${ }^{170}$ See Art 5 TEU.

${ }^{171}$ See Young, 'Protecting Member State Autonomy' (n 55) 1631, 1641; Lenaerts, 'Federalism: Essential Concepts' (n 47) 747.

${ }^{172}$ See Case C-376/98 Tobacco Advertising, para 84.

${ }^{173}$ See Young, 'Two Cheers' (n 168), 1367-1373

${ }^{174}$ See Lenaerts, 'Process-Oriented Review' (n 32) 3-4, 15-16; John Hart Ely, Democracy and Distrust (Harvard University Press, 1980); United States v Carolene Products Company, 304 U.S. 144 (1938), n 4.

${ }^{175}$ See Young, 'Two Cheers' (n 168) 1354, 1358, 1366; Young, 'Protecting Member State Autonomy' (n 55) 1646-53.

${ }^{176}$ See Schütze (n 17) 261-62, 266; Laurence H Tribe, ’The Puzzling Persistence of Process-Based Constitutional Theories' (1980) 89 Yale Law Journal 1063.
} 